\title{
Empowerment among small farmers of Sindh province, Pakistan
}

\begin{abstract}
Community empowerment is an important goal for many governments in developing countries. Various activities for the empowerment of communities have been conducted in developing countries like Pakistan. The present research attempted to assess an activity of community empowerment on the Crop Maximization Project (CMP-II) in Sindh province, Pakistan. A total of 455 small farmers were surveyed using questionnaire in three districts namely; Khairpur, Nawabshah and Mirpurkhas. The level of empowerment was assessed based on three domains namely; capacity building, self-esteem and self-efficacy. The findings of the study showed that, there was a moderate level of empowerment among the beneficiaries (small farmers) of the crop maximization projects of the Sindh province based on a summed mean score of 178.77 for the three dimensions of empowerment. Therefore, it is concluded that projects like crop maximization are able to empower the beneficiaries as the intangible outcomes.
\end{abstract}

Keyword: Community development; Community empowerment; Small farmers; Capacity building; Self-esteem; Self-efficacy 